\title{
A Statistical Analysis and Empirical Study of Investors Behaviour in Mutual Fund Market
}

\author{
Maitreya N. Acharya \\ Department of Statistics, Maharaja Krishnakumarsinhji Bhavnagar University, Bhavnagar, Gujarat, India
}

\begin{abstract}
An important segment of financial markets is the field of mutual funds. So far, mutual funds have delivered value to the investors. Not a single industry can flourish without a proper regulatory mechanism. Here are some initiatives which would help towards making the Indian mutual fund industry more vibrant and competitive. Here, the need of study has been aroused in order to see the factors influencing the retail investment regarding the mutual funds in the state of Gujarat. Our study is based on testing of hypotheses as under.
\end{abstract}

Keywords: Mutual fund, Retail investors, Indian investors, Variables influencing investorse decision, Investors profile variables, Dependent and Independent variables.

\section{Introduction}

During last few years, the Indian capital market has been increasing in a tremendous manner. Many developments have taken place in the Indian financial market with the reforms in the field of economy, industrial policy, public and financial sectors. As a result, the economy has opened up. Indian mutual fund industry came into existence in the year 1963 as a part of development in the capital market. It has become an important and dynamic sector of the Indian capital markets particularly in the past five years.

\section{Literature Review}

- It has been reviewed by Agarwal R.K. et al. (2010) that the performance of mutual funds has been receiving a great deal of attention from both practitioners and academics. The interest of the public in investment is understandable with an aggregate investment of trillion dollars in India. The goal of identifying superior fund managers is interesting as it encourages development and application of new models and theories as far as academic perspective is concerned. It is also our aim to identify the out performers for healthy investments. We have also ranked the investment opportunities for better evaluation of these funds based on various adjusted ratios like Sharpe ratio, Jensen Measure, Fama ratio,Sortino ratio, Treynor's ratio and few others. Therefore, an attempt has been made to capture the critical measures of performance evaluation of mutual funds.

- It was studied by Giridhari Mohanta \& Dr. Sathya Swaroop Debasish (2011) that investors invest in different investment avenues for fulfilling their financial, social and psychological needs.

- An attempt was made by Haslem, Baker and Smith (2008) to investigate the relation between performance and expense ratios of 1,779 domestic, actively managed retail equity funds. They concluded that superior performance, on average, occurs among large funds with low expense ratios, low trading activity and no or low front-end loads.

- Agapova (2011) found that cash flow volatility is positively and negatively related as far as investment and opinions related to investments in the families are concerned.

- Cao, Ghysels \& Hatheway (2011) have investigated global funds and specialized domestic equity fund. They found that risk and return characteristics of these two groups of funds are significantly different from funds employing derivatives sparingly or not at all.

\section{Need for the Study}

The study reveals the influence of risk orientation on investment as far as demographic factors, education, human mentality, gender and age are concerned.

\section{Objective of the Study}

To know the influence of investment behavior of the individual investor on the basis of parameters like age, education, mentality, gender and demography.

\section{Null Hypothesis}

Investment and education are the two independent attributes in mutual fund investment as far as males and females are concerned.

\section{Alternative Hypothesis}

Investment and education are the two dependent attributes in mutual fund investment as far as males and females are concerned. In order to study the above hypotheses, we use the statistical technique of one-way analysis of variance.

\section{Methodology}

- Our questionnaire consists of total 35 questions out of which first 15 questions were focused to know the demographic characteristics of the investors.

- Next 4 questions were to find the risk orientation of the investor and rest of the questions were to find the other objectives of the study.

- The survey was conducted with a sample size of 256 investors of Gujarat.

- Here in this paper, we only discuss the risk orientation and investment trend in mutual funds. On the responses of the questionnaire, analyses have been carried out. We have used statistical tool ONE WAY ANOVA for this purpose. 


\section{International Journal of Science and Research (IJSR) \\ ISSN (Online): 2319-7064}

Index Copernicus Value (2013): 6.14 | Impact Factor (2015): 6.391

- The details related to education groups are given below in Table-1.

Table 1: Education Group Details

\begin{tabular}{|c|c|c|}
\hline Name of Age Group & Category & Comments \\
\hline High School dropout & 1 & $\begin{array}{c}\text { Did not complete high } \\
\text { school education }\end{array}$ \\
\hline High School pass out & 2 & $\begin{array}{c}\text { Completed high school } \\
\text { education }\end{array}$ \\
\hline $\begin{array}{c}\text { Attended College (but } \\
\text { not a graduate) }\end{array}$ & 3 & Graduation Incomplete \\
\hline College Graduate & 4 & Graduated from college \\
\hline Post Graduate and more & 5 & Master"s degree \& Ph.D. \\
\hline
\end{tabular}

\section{Analysis of the Survey}

The important components of any investment are the role of uncertainty and the lack of financial knowledge about the return over investments avenues among the investors. The ability of investors to tolerate the risk of return is referred to as risk tolerance (Schaefer 1978). As far as the expert's opinion is concerned, risk tolerance always tends to be subjective rather than objective. Moreover, we have discussed the attributes related to demography such as gender, education, mentality and age in the graphs as under. Further, we note that the height of the bar chart and the length of error bar indicate the values of mean and standard error respectively.

\section{Explanation of Graphs}

\section{Graph 1: Gender}

Our study shows the dominance of male investors over female investors as far as the individual contribution in the total investment is concerned. It is so because the males have more financial responsibility as compared to the females.

\section{Graph 2(a) and 2(b): Age Factor (Youngsters)}

It was found that age group of 30-45 (both males and females) has maximum investment which clearly indicate the keen interest of youngsters to invest in the mutual fund market.

\section{Graph 2(c) and 2(d): Age Factor (Young, Middle Aged and Old)}

From our study, it was found that age groups of 18-30 and $30-45$ have the maximum number of investors. In case of middle aged and old people, the age group 45-60 (males) has minimum number of investors while in case of females, the age group over 60 has minimum number of investors.

Note: The length of the error bars (standard errors) show that age groups have approximately the same spread.

\section{Graph 3(a) and 3(b): Income Factor}

Here, the graphs show personal income per month and education group among male and female investors. Mostly, the male investors with a graduate degree were found to invest some part of their salary in mutual funds while the females with graduate degree and females who went to college but somehow could not complete their college education were found to be investing more in mutual funds.
Graph 4(a) and 4(b): Education Level and Investors Behaviour

Here, the graphs show of education level among the male and female investors. In case of males and females, highest investors were found in the education group of high school drop outs and college graduates. Minimum numbers of investors were found among females with graduate degree and more and same was the result in case of males who were just high school drop outs.

\section{Graph 4(c) and 4(d): Education Level and Personal Investment}

These graphs show the relation between the personal investment per month and their education group among male and female investors. The graphs reveal that as the increase in the values of mean is directly proportional to the increase in the values of standard deviations. Actually, they should be completely independent. Our graphs show that the value of standard error differs for different education group as far as male investors are concerned. The graphs clearly indicate that the highest portion of the investment among both (male and female) investors is of those with graduate degree and more and the least part is of the high school dropout investors. Some college dropout females and graduate males are second highest in the category of female investors and male investors respectively.

\section{Graph 5(a) and 5(b): Square Root of Personal Investment and Educational Qualification}

The graphs show the relation between square root of personal investment per month and their education group among the male investors. We can easily note that there is less difference in length among the error bars (standard deviations) if we take the square root of each investment value, which indicates that there is less variability among the standard deviations, and the relation between the means and standard deviations is weaker. We note that after transformation, their dependency gets eliminated.

\section{Graph 6(a): Least Square Means of Square Root of Investment of five different education group of Male Investors}

This graph shows the average value of the transformed male investment for each level of the education group of male investors. Further, it reveals that male investors in the education group of college drop outs and those with college graduate degree have similar average investment in mutual funds. Further, it is clear that the education group with a graduate degree and more has maximum average investment in mutual funds. It was found in recent study that "Education" plays a vital role as far as investment of males is concerned.

Graph 6(b): Least Square Means of Square root of Investment of five different education group of Female Investors

This graph shows the average value of the transformed female investment for each level of the education group of the female investors. It clearly reveals that female investors having different education group have different average investment in mutual fund market. It is clearly found that just like male investors, female investors in education group 


\section{International Journal of Science and Research (IJSR) \\ ISSN (Online): 2319-7064 \\ Index Copernicus Value (2013): 6.14 | Impact Factor (2015): 6.391}

with graduate degree and more has maximum average investment in mutual funds.

\section{Explanation Regarding Null Hypothesis}

Here, we perform ONE WAY ANOVA at 5\% level of significance. We get the results of ANOVA Table-1 is by taking the transformed investment of male investors as the dependent variable and five education groups of male investors as the category variable. From ANOVA Table-1, it is quite clear that there is a significant difference among the four means of education groups of male investors with $p$ value $=0$ ( $p$-value $<0.0005)$. Hence, it was found that education group is significant. Thus, at least one of the education groups differs from the other with respect to investment.

\section{Explanation Regarding Alternative Hypothesis}

Here also, ONE WAY ANOVA technique is used at 5\% level of significance. Here, we have compared the average investment of female in mutual funds for five education groups of female investors. The p-value obtained here is 0.001 (see ANOVA Table-2) which is more than 0.0005 . The education group effect on investment of females is not significant ( $p$-value >0.0005). Hence, average investment and education are the two independent attributes of the female investors.

\section{Conclusion}

We come to the conclusion that investors having different education group have different average investment in mutual funds. On the basis of the results obtained as per the ONE WAY ANOVA TECHNIQUE, it is quite clear that investors in the education group with graduate degree and more have maximum average investment in mutual funds. That is why the present study looks at the perception level of the investors towards investment in mutual funds. Presently, more and more funds are entering the industry. Their survival mainly depends on their marketing strategies because they need to survive and thrive in this highly promising industry, in the face of such cutthroat competition. Therefore, the mutual fund industry today needs to develop products to fulfill customer needs and their education.

\begin{tabular}{|c|c|c|c|c|c|}
\hline \multicolumn{6}{|c|}{ ANOVA Table (1): Hypothesis Testing (Males) } \\
Test of Hypothesis \\
\hline Source & SS & df & $\begin{array}{c}\text { Mean } \\
\text { Squares }\end{array}$ & F-ratio & p-value \\
\hline $\begin{array}{c}\text { Between education } \\
\text { groups (Male } \\
\text { Investors) }\end{array}$ & 6862.358 & 4 & 1715.59 & 7.854 & 0 \\
\hline $\begin{array}{c}\text { Within education } \\
\text { groups (Male } \\
\text { Investors) }\end{array}$ & 21625.65 & 99 & 218.441 & & \\
\hline
\end{tabular}

ANOVA Table (2): Hypothesis Testing (Females)

\begin{tabular}{|c|c|c|c|c|c|}
\hline \multicolumn{7}{|c|}{ Test of Hypothesis } \\
\hline Source & $S S$ & $d f$ & $\begin{array}{c}\text { Mean } \\
\text { Squares }\end{array}$ & $\begin{array}{c}F- \\
\text { ratio }\end{array}$ & $\begin{array}{c}p- \\
\text { value }\end{array}$ \\
\hline $\begin{array}{c}\text { Between education } \\
\text { groups (Female } \\
\text { Investors) }\end{array}$ & 4399.949 & 4 & 1099.987 & 5.011 & 0.001 \\
\hline $\begin{array}{c}\text { Within education } \\
\text { groups (Female } \\
\text { Investors) }\end{array}$ & 32267.338 & 147 & 219.506 & & \\
\hline
\end{tabular}

Graphs:

All the graphs explained earlier are shown below with titles and subtitles and different categories.

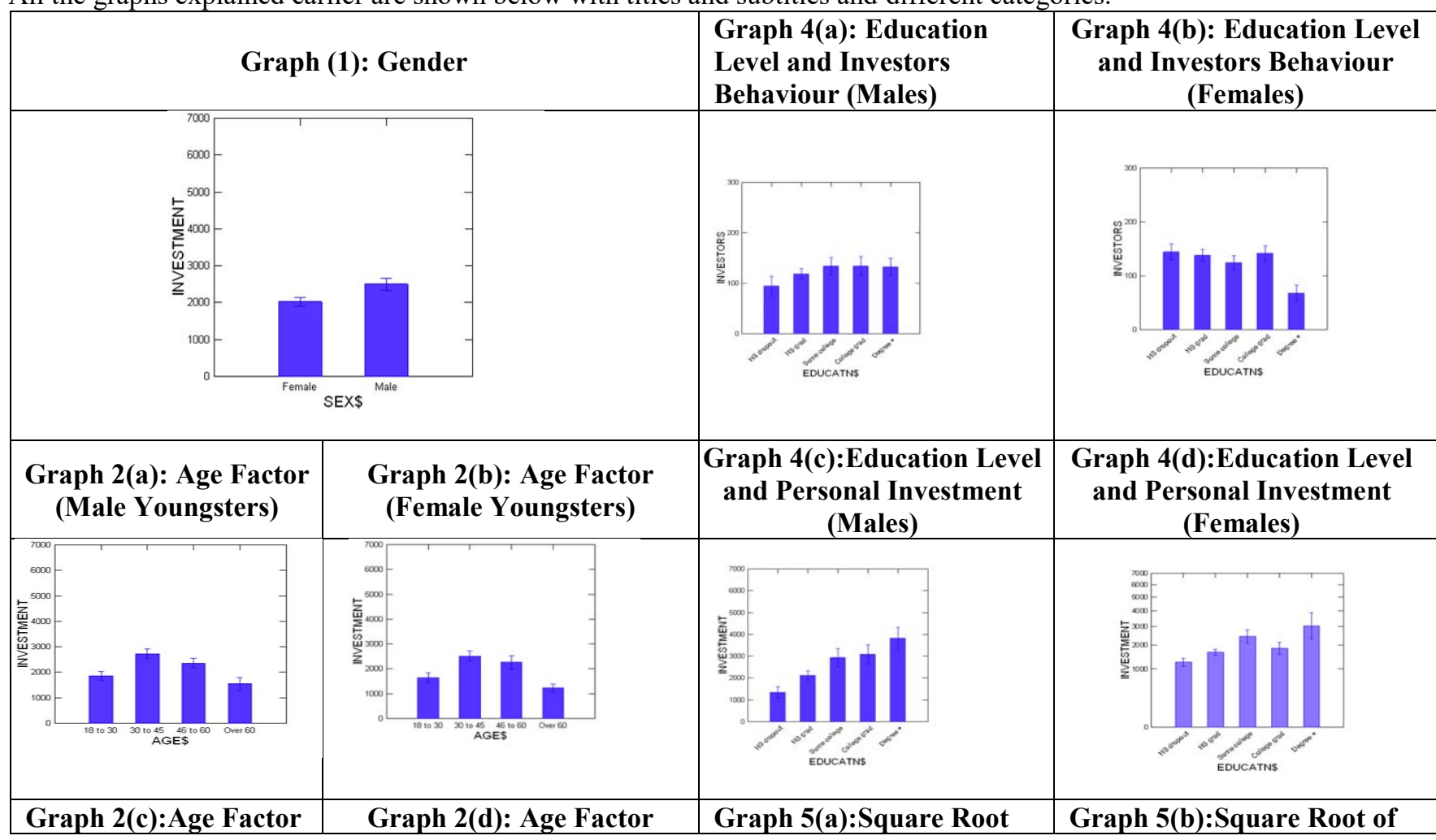


International Journal of Science and Research (IJSR)

ISSN (Online): 2319-7064

Index Copernicus Value (2013): 6.14 | Impact Factor (2015): 6.391

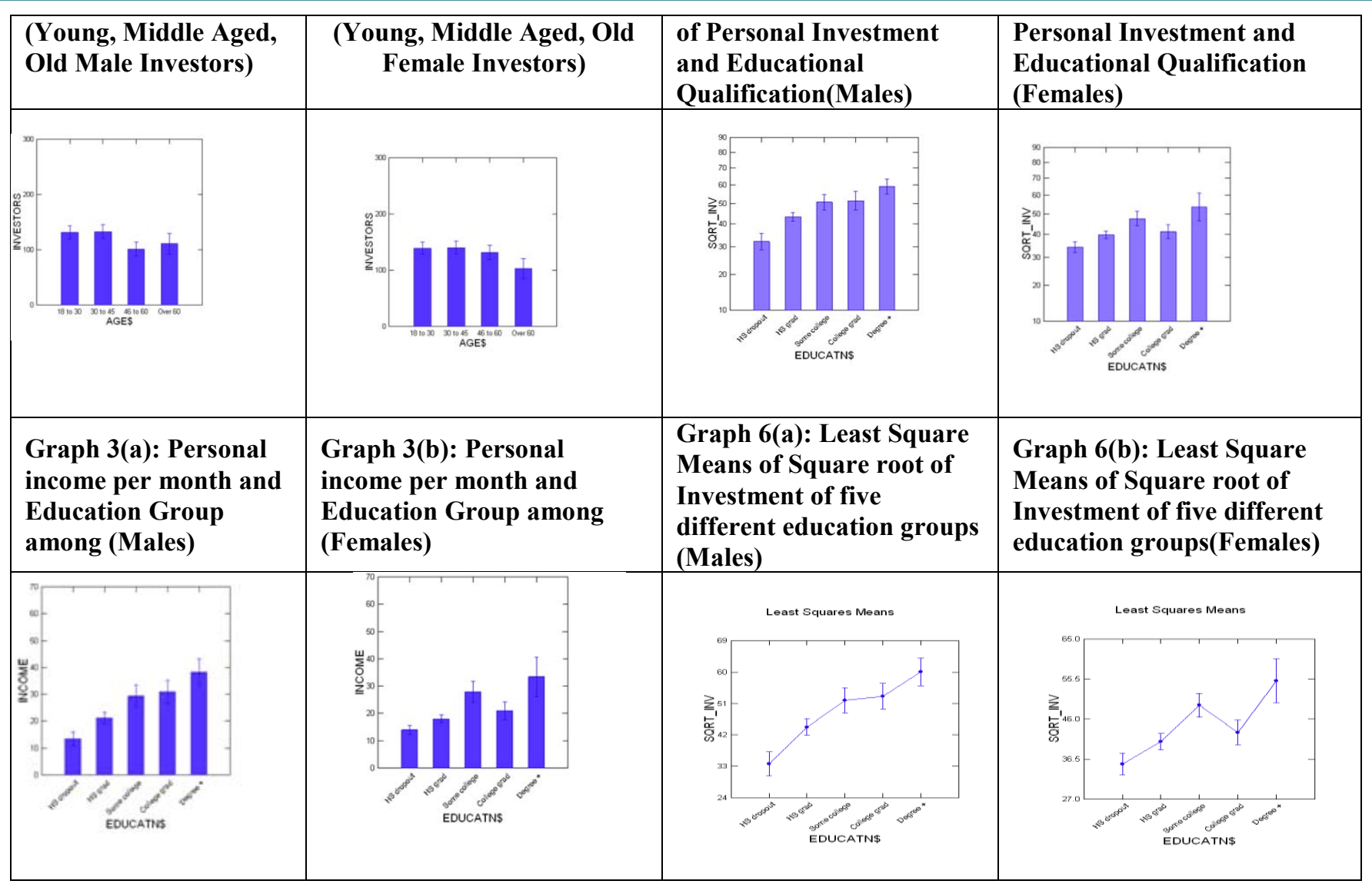

\section{References}

[1] Agapova, Anna, (2011) "The Role of Money Market Mutual Funds in Mutual Fund Families", Journal of Applied Finance, Vol. 21, Issue 1, pp. 87-102,

[2] Aggarwal, R. 1981. Exchange rates and stock prices: case study U.S capital markets under floating exchange rates. Akron Business and Economic Review, 12: 7-12.

[3] Badrinath, S.G \& Gubellini, S, July (2011) "On the characteristics and performance of long-short, marketneutral and bear mutual funds" Journal of Banking \& Finance, Vol. 35 Issue 7, p1762-1776

[4] Giridhari Mohanta \& Dr. Sathya Swaroop Debasish (2011) "A Study on Investment Preferences among Urban Investors in Orissa" Prerna Journal of Management Thought and Practice, ISSN: 0974-908X volume: 3 Issue: 1 March 2011, pp 1-9

[5] Cao, Charles; Ghysels, Eric \& Hatheway, Frank, July (2011) "Derivatives do affect mutual fund returns: Evidence from the financial crisis of 1998", Journal of Futures Markets, Vol. 31 Issue 7, pp. 629-658

[6] Aman Srivastava (2007). An Analysis of Behaviour of Investors in India, ICFAI Journal of Behavioural Finance, June, Vol. 4, No. 2, pp.43-52.

[7] Badrinath, S.G \& Gubellini.S July (2011) "On the characteristics and performance of long-short, marketneutral and bear mutual funds" Journal of Banking \& Finance" Vol. 35 Issue 7, p1762-1776.

[8] Bala Ramasamy, Matthew C.H. Yeung (2003). Bhattacharya, B. 2002. Causal relationship stock market and exchange rates, foreign exchange reserves, values of trade balance: A case study of India. Cited from www.igird.ac.in.
[9] Black, A. et. Al. 2001. US Stock price and macro economics fundamentals. Aberdeen Working Papers, $1-3$.

[10] Cao, Charles; Ghysels, Eric \& Hatheway, Frank , July (2011) "Derivatives do affect mutual fund returns: Evidence from the financial crisis of 1998", Journal of Futures Markets, Vol. 31 Issue 7, pp. 629-658

[11] Fadhil, MH. Azizan, NA. and Shaharudin, RS. 2007.The interaction between macroeconomic variable and the performance of mutual fund in Malaysia. $M F A$ $9^{\text {th }}$ conference -12 th and 13 th June.

[12] Giridhari Mohanta \& Dr. Sathya Swaroop Debasish (2011) "A Study on Investment Preferences among Urban Investors in Orissa" Prerna Journal of

[13] Management Thought and Practice, ISSN: 0974-908X volume: 3 Issue: 1 March 2011, pp 1-9.

[14] Haslem, John A., Baker and Smith, "Performance and Characteristics of Actively Managed Retail Equity Mutual Funds with Diverse Expense Ratios,"

[15] Financial Services Review, Vol 17, Issue 1, Spring 2008, pages 49-68.

[16] Nath, GC. Samanata, GP. 2000. Integration between forex and capital markets in India: an empirical exploration. Applied financial Economics, 7: 25-35.

[17] Sarkar, S. Sarkar, T. 2005. Reforming financial markets in India"s strategic approach. SSRN.960532

[18] Singh Jaspal and Chander Subhash (2004). An Empirical Analysis of Perceptions of Investors towards Mutual Funds, Finance India, December, Vol. 18, No.4, pp.1673-1692.

[19] Sultana Tabassum Syed (2010) an Empirical Study of Indian Individual Investors Behavior, Global Journal of Finance and Management, ,ISSN 0975 -6477 Volume 2, Number 1 (2010), pp. 19-33. 